\title{
SOCIO-PEDAGOGICAL SUPPORT TO YOUTH PARTICIPATION IN INTEGRATION PROCESS
}

\author{
Tamara Pigozne \\ University of Latvia, Latvia \\ Aivars Pigoznis \\ Rezekne Art and Design Secondary School, Latvia
}

\begin{abstract}
The purpose of the article is on the basis of theoretical formulations to analyze participation and integration as pedagogical category and socio-pedagogical means, facilitating the participation of youth in integration process in two aspects - in educational system and labour market, linkages between participation and understanding the integration as terminal (related to life goals), instrumental (means of reaching life goals) and opportune (related to opportunities) value as well as implicants of efficient participation.
\end{abstract}

Keywords: integration, participation, socio-pedagogical support, values, recognition, trust, encouragement, respect, empathy, cooperation, mentoring.

\section{Introduction}

In the planning documents of Latvia and Europe youth is defined as one of priority target groups concerning arrangements of active labour market policy, the sphere of education as well as poverty and social exclusion reduction, as despite the fact that the number of unemployed youth and early school leavers slightly decreases, in recent years the youth unemployment rate and the number of early school leavers in Latvia remains one of the highest among the member states of the EU. The main directions of activities in these spheres of politics are aimed at reduction of youth unemployment and its integration into the labour market, youth social protection, youth poverty reduction and ensuring the youth education quality and development of skills (Informative Report on Youth Guarantee Implementation in Latvia in 2014-2018, 2013). In accordance with the set priorities - intelligent, sustainable and integrating growth - the aims of the strategy "Europe 2020" are reduction of the number of the younger generation population who are early school leavers and increase of the proportion of this target group having the higher education and employment (European strategy for smart, sustainable and inclusive growth, 2010). Consequently, the main challenges in reduction of these problems is to return youth to the educational system and ensure education to meet the labour market needs as well as raising the qualification of unemployed youth and development of skills according to the needs of labour market. Implementation of the offered 
Tamara Pigozne, Aivars Pigoznis. Socio-Pedagogical Support to Youth Participation in Integration Process

solutions for elimination of early withdrawal from education and training (AIIA), in three political courses (prophylaxis, intervention and compensation) includes provision of the support which is adapted to target audience, thus raising an issue in this context on integration of youth in education and labour market and the necessity, opportunities and efficiency of socio-pedagogical support (Eurydice Brief: Early Leaving from Education and Training, 2015). Education level directly correlates with the employment, unemployment and poverty as well as social exclusion risk indicators. People having basic education level are the most likely exposed to a high risk of poverty and social exclusion; and the higher is the level of acquired education, the lower is the poverty risk (Informative report on youth guarantee implementation in Latvia 2014 - 2018, 2013). It is important to be aware of contextual factors while working with youth in a target group (Methodical guidelines for work with the youth in a target group in the project "KNOW and DO!", 2015). Nowadays a lot of criticism is devoted to policy, which stresses reduction of social exclusion consequences and relates youth to social risks, in management of which the determining factors are intervention and control, instead of "systematic support, continuity and persistent application of dynamic enabling techniques" and prevention.

Youth education and employment topicality in the context of Latvia and Europe determined the need in research aimed at defining the means of sociopedagogical support to facilitate integration of youth participation in educational system and labour market as well as find an answer to the research question whether and how does the understanding of youth integration as value influence youth participation.

\section{Theoretical Framework}

In the context of the research integration is defined as a task of development (Held, 2009), capacity to act (Kalpaka, 1986; Held \& Riegel, 1999; Riegel, 2009), which emphasizes the need in perceiving integration as an ability to use resources, accentuating the capacity to act (participation), action competence (Buchkremer, 1995), which manifests itself in following dimensions: advising, help, presentation, informing, teaching, organisation, management, planning; process of personality development or personality "socialization" (Kreckel, 1994).

Recognition is a mutual process (Riegel, 2004) and is related to effort of integration (Flusser, 1994), based on the „participation work” (Mecheril, 2003). Affiliation work appears as self-cultivation described as an active attitude of a person towards oneself (Mecheril, 2003:342) and which appears as selfdisciplining, self-restraint, self-confidence, self-compliance as well as self-denial. 
To describe the effort of integration at the level of an individual (personality), Paul Mecheril uses a metaphor of „garden”. As P. Mecheril sees it, the future-oriented affiliation work is a process where "the gardener him/herself cultivates a garden inside him/herself". The author relates the work of selfcultivation with responsibility towards oneself. The philosophy of "gardening" includes observation, attention and knowledge - a person must understand at least something about growing, decay, life and death. Cultivation of garden is simultaneously a form of changing and preserving, supervision and control, however, it may not become repressive. Cultivation is maintaining influence which is reserved and considered. Garden faces the influence - intervention, trust, waiting. Self-cultivation includes the forms of self-change facilitated by self-observation and self-influence. Responsibility influences the results and practice. Everyone is responsible for oneself $-\mathrm{s} /$ he does cultivate her/himself or does not. Responsibility creates the capacity to act voluntarily and predict consequences of an action. Self-development is possible only by the means of obligations which a youth accepts and acknowledges. Responsibility is an important precondition for self-cultivating attitude.

One of the most important conditions of integration is to create situations of communication and cooperation. One of the most important conditions of integration is to create situations of communication and cooperation. The basic criterion of integration is to what extent it facilitates the progress, welfare and freedom of personality (Karpova, 1994).

The causes of unemployment are categorized in two basic groups: structural causes, related to economic system and labour market and personal causes, related to skills and personality traits influencing access to labour market. Basing on the socio-psychological theories dealing with the study of attitude and behaviour of the unemployed, the authors of the research (Working on Work for all, 2010) emphasize the individual outlook of unemployment, thereby activating such socially conditioned traits of personality as selfevaluation, level of claims, self-esteem, locus of control and values. Values in terms of important and sustainable conviction or ideals (Morales \& Sheafor, 2011) influence the behaviour, attitude and interaction of the involved persons as well as the efficiency of support and help (Parsons, 2011). The idea on integration as an opportune value, topical to the youth searching and discerning new self-fulfilment opportunities in educational system and labour market (opportuneness) develops on the basis of the theory by Milton Rokeach (Rokeach, 1979) on values as life objectives (terminal) and values as means to achieve life objectives (instrumental).

The authors of the research (Working on Work for all, 2010) have classified the solutions for the youth unemployment issue, relating them to three main ideas: positive thinking, encouragement for young job searchers and 
reduction of social exclusion. Positive thinking begins with introduction of changes in the language and moral attitude, while solving the issue of unemployment, for instance, speaking about "young job searchers" instead of "young unemployed people", focusing on resources and abilities instead of disadvantages etc. Positive thinking is related to the need in analysing the unemployment situation not only in a negative way, but also understanding the potential positive influence it might have, at least, what concerns several life aspects, trying to create opportunities out of the complicated unemployment situation. The authors of the research base on the insight expressed by Paulo Reglus Neves Freire in his work "Pedagogy of the Oppressed" that encouragement comes from practice: encouragement is a cyclic process of experimental learning when an individual evaluates the current life situation, identifies the things s/he would like to change, acts to make the changes happen, and then reflects the action (1970). Thus, encouragement is a continuous process of changing. This idea of encouragement as a continuous releasing process corresponds to the practical examples and work experience of the young job searchers. Encouragement indirectly points out to a continuous process consisting of development of practical skills and social competences, providing support to change attitude, cooperation and promotion of social networks' creation. The mechanisms of the link between unemployment and social exclusion are complicated and complex therefore it is necessary to develop a holistic approach to it. Overcoming unemployment is a problem-solving strategy. The authors of the research point out that in the "situation of many problems" social workers often apply the method of existential psychotherapy, which was developed and used by Viktor Emil Frankl (1946), interviewing holocaust inhabitants and revealing that they could survive in extreme situations, as they could create something (with hands or intellectually), deeply believed in something and were attached to something - they has an emotional support and deep relationships with someone. The support provided to the young job searcher in this "situation of many problems" will be efficient if these needs are implemented.

The authors of the research on the needs in training and interests of youth in remote or underdeveloped regions (Sniksere et all, 2010) accentuate that conceptualizing the experience of foreign countries in work with youth, there are three main theoretical approaches - preventive approach, flexibility approach and positive development approach (Small \& Memmo, 2004). The youth's positive development approach is based on the following assumptions:

- assistance to youth in implementation of their opportunities is the best way to protect them from problems;

- $\quad$ in order to improve one's personality youth need to feel support and discern opportunities; 
- local municipalities need to increase the capacity aimed at support to youth in their efforts;

- youth should not be viewed as a problem to be solved, but as partners, which should be involved and whose acquirements should be developed.

The authors of the project "Youth in Labour Market: Analysis of the Situation and Factors Influencing Employment" (2007) referring to Thomas Loren Freedman (Freedman, 2005), point out that while evaluating and researching youth employment the International Labour Organisation along with ensuring equal opportunities, active labour market policy, creation of employment (workplaces), business, role of social partners, emphasize also such an important aspect as participation of young people. The authors of guidelines for youth participation base on the definition by the U.S. National Commission on Resources for Youth, that youth participation is "involving youth in responsible, challenging action that meets genuine needs, with opportunity for planning and/or decision-making affecting others, in an activity whose impact or consequences extends to others - outside or beyond the youth participants themselves" (Youth Participation Guide: Assessment, Planning and Implementation, 2008:25). Participation is ,a way of being, an ethic of practice, which informs how individuals and groups respond to issues and problems" (Percy-Smith \& Thomas, 2010:362). Tiina Sotkasiira, Lotta Haikkola and Liisa Horelli (Sotkasiira, Haikkola \& Horelli, 2010) distinguish participation and active participation, and referring to previous studies arrive at conclusion that actually "participation does not automatically ensure youth the capacity to lead their lives"; as "youth participation seldom emerges on its own", it needs intellectual and material resources and interaction of various social structures. Active participation influences transformation of youth living conditions and improvement of its civic skill. Moreover, since youth participation almost always embodies contradiction between control and freedom, "learning-based network approach to planning" offered by the authors is one of the ways to advance efficient youth participation. The structure of the approach is based on "a model of planning, specific tasks of development, and a collective monitoring and self-evaluation system".

Dieter Schulz (Šulcs, 2005:6) supplements the view adding trust as a basic need of young people in relationships with their parents and other people as a basis of educational thinking and action, as it unites, supports and facilitates sustained development as a ground for building all the processes of development education and socialization. He emphasizes that among many forms of social interaction trust is the core bulwark. One of the three his basic conclusions is: "(..) the things what children and young people actually accept depend on the relationships between parents/educators and their children; teachers and their 
Tamara Pigozne, Aivars Pigoznis. Socio-Pedagogical Support to Youth Participation in Integration Process

pupils; masters and their apprentices (or on the relationships the mentioned people are able to build). Thus, it depends on the capacity to build relationships (..) and the capacity to create trustful relationships." When speaking of the concept „trust”, the youth themselves speak of five dimensions: personal attitude, professional competence and assistance, respect, availability, frankness.

Karen Jones believes that trust may be defined as a feeling as well as a judgment and a disposition to act. Trusting somebody means that one has an attitude of optimism about the goodwill and the competence of the other person as it extends to the sphere of one's interaction with them including an expectation that the other will be guided by the thought that we are counting on them (Jones, 1996:15).

An efficient strategy facilitating youth participation and helping them to adapt themselves to the educational system and labour market is mentoring. Mentoring is a relationship between a less experienced individual and a more experienced individual, who becomes an advisor or mentor; a supervision of a senior over a beginner in some field aimed at facilitation his or her professional, academic or personal development (Donaldson, Ensher, \& Grant-Vallone, 2000), where mutual confidence and respect prevails, regular interaction of the involved parties takes place, the relationship based on cooperation, learning and support between the individual, who shares his/her knowledge, experience and wisdom, and the individual who is ready and willing to gain from this exchange and enrich own professionalism or personal development (Methodical Guidelines for Work with the Youth in a Target Group in the Project "KNOW and DO!", 2015).

Participation is a category of integration (Weber, 2007), but categories of participation are co-determination, co-distribution and contribution (Arnstein, 1969, Klafki, 1990, Warren, 1993, Olk, 1994, Flusser, 1994, Petersen, 1999, Otto, Thiersch, 2001, Maslo, 2002; Kirby et all, 2003; Checkoway, 1998; Checkoway \& Richards-Schuster, 2003), and it is crucial to ensure the youth opportunities to implement them. Leni Dam and Britta Hufeisen (Dam, Hufeisen, 1995:10) have elaborated an interaction model of the learning process components "objectives", "pupil's role", "teacher's role", "action", "materials", "self-assessment"; the model is topical for facilitation of pupils' participation. The set aims: to ensure pupils with the opportunities of co-distribution, contribution, co-determination, to advance dialogue opportunities between a teacher and pupil and pupil and pupil, to involve pupils in creation of learning process, to perform self-assessment, teachers to cooperate with pupils on the choice of work form, methods and content, whereas pupils to be co-deciding and co-responsible for the choice of work form, methods and content and own learning. Marie Harder, Gemma Burford and Elona Hoover view participation in 3 dimensions - depth, what concerns control over decision-making, breadth, 
which includes the diversity of the people interested in participation, and scope, focused on the stages of the central decisions, analysing education at six levels:

- Denigration - indigenous knowledge (IK) which are explicitly denigrated in formal curricula;

- $\quad$ Neglect - IK not explicitly denigrated, but devalued by omission from mainstream curricula;

- Acknowledgement ('learning about') - IK described in formal curricula, usually by outsiders. Indigenous involvement in decisionmaking is quite limited or non-existent;

- Engagement ('learning from') - emphasizes the merits of IK, but it is still seen as inferior. Limited indigenous involvement in decisionmaking, for instance, by boundary spanners;

- Interculturality ('learning together') - Recognition of equal status and collaborative decision-making, but dichotomy is still present;

- Full partnership ('learning as one') - Problem-based, change-oriented learning dissolves 'us and them' mindset, creating new knowledge towards shared goals. Decision-making is fully collaborative (Harder, Burford \&Hoover, 2013:45).

Participation is not only self-confidence, but also a tool of evaluation, selfevolution in the process of integration (Warren, 1993).

\section{Methodological Framework}

263 young people at the age of $15-29$ took part in the research. Profile of the respondents:

- $\quad$ gender (111 men and 152 women);

- $\quad$ place of residence (165 respondents live in city, 98 - in rural areas);

- education (54 respondents have higher education, 89 - secondary education, 69 - professional education, 51 - elementary education);

- employment (64 employees, 23 entrepreneurs, 11 self-employed persons, 68 unemployed persons, 84 pupils/students, 13 NEETs);

- knowledge of foreign languages (152 respondents know 1 foreign language, 92 respondents know 2 foreign languages and 19 respondents know 3 or more foreign languages);

- experience of informal and non-formal education (186 respondents who have experience of informal and non-formal education and 77 respondents who do not have any such experience).

Questionnaire contained closed questions about comprehension of integration as valuable issue, co-determination, contribution, co-distribution as categories of participation, as well as about events which facilitate participation 
Tamara Pigozne, Aivars Pigoznis. Socio-Pedagogical Support to Youth Participation in Integration Process

in integration education and labour market, using Likert scale for their assessment, and opened questions about positive experience in education or labour market, the received support and opportunities of the usage of forms and methods which facilitate participation. The obtained primary data were encoded according to the code system elaborated in theoretical guidelines, thus creating codes, profile codes and content (conceptual) codes - multiple and metacodes of the respondents. In the beginning of the research there were used several data statistical analysis methods, such as Cronbach's Alpha coefficient for questionnaire indicator's (questions) credibility and concordance check, establishing a sufficiently high concordance (Cronbach's Alpha coefficient values are in the range from 0,861 until 0,909), and Kolmogorov-Smirnov's test to establish the distribution of results, influencing the need in choice of nonparametric data processing methods (the distribution did not match the normal $(p=0.001))$. With the help of approach of compound methods, primary quantitative data of the research were processed in the environment of program SPSS which in intended for processing of quantitative data, using Chi-Square test, Mann-Whitney U-test, Kruskal-Walis H-test, Kendall's tau-b correlation analysis and cluster analysis. Conversely, qualitative data were processed in environment of program AQUAD which in intended for processing of qualitative data, creating tables of frequencies for determination of code frequency, linkages and implicants, thus ensuring triangulation.

\section{Findings and Discussion}

The results of Kendell's (Kendall's tau-b) correlation prove that there is a positive correlation between socio-pedagogical means and participation - such socio-pedagogical means as trust, empathy, recognition, respect, encouragement, cooperation and mentoring are facilitated co-determination, co-distribution and contribution (see Table 1). There is a very high positive correlation between codetermination and recognition, empathy; contribution and encouragement, cooperation; co-distribution and trust, respect; all the categories of participation and mentoring.

As well, the results of Kendell's (Kendall's tau-b) correlation analysis show that there is a high positive correlation between understanding integration as a value related to opportunities (opportunate) and participation (see Table 2). There is a very high positive correlation between understanding integration as an opportunate value and trust, cooperation as well as mentoring. Trust and cooperation facilitate understanding of integration as opportunate value, encouragement and empathy facilitate understanding of integration as instrumental value, but recognition and respect facilitate understanding of 
integration as a terminal value. Mentoring facilitates understanding of integration as opportunate and instrumental value.

Table 1 Correlations between participation categories and means of socio-pedagogical support

\begin{tabular}{|c|c|c|c|c|c|c|c|}
\hline \multirow{2}{*}{$\begin{array}{l}\text { Categories of } \\
\text { participation }\end{array}$} & \multicolumn{7}{|c|}{ Means of socio-pedagogical support } \\
\hline & $\begin{array}{l}\text { Recogni- } \\
\text { tion }\end{array}$ & Trust & $\begin{array}{c}\text { Encourage- } \\
\text { ment }\end{array}$ & Respect & Empathy & $\begin{array}{c}\text { Coopera- } \\
\text { tion }\end{array}$ & Mentoring \\
\hline $\begin{array}{l}\text { Co- } \\
\text { determination } \\
\end{array}$ & $\begin{array}{l}\mathrm{r}=0.93 \\
\mathrm{p}=0.000\end{array}$ & $\begin{array}{l}\mathrm{r}=0.71 \\
\mathrm{p}=0.000\end{array}$ & $\begin{array}{l}\mathrm{r}=0.69 \\
\mathrm{p}=0.000\end{array}$ & $\begin{array}{l}r=0.53 \\
p=0.000\end{array}$ & $\begin{array}{l}\mathrm{r}=0.90 \\
\mathrm{p}=0.000\end{array}$ & $\begin{array}{l}r=0.70 \\
p=0.000\end{array}$ & $\begin{array}{l}r=0.91 \\
p=0.000\end{array}$ \\
\hline Co-distribution & $\begin{array}{l}\mathrm{r}=0.49 \\
\mathrm{p}=0.000\end{array}$ & $\begin{array}{l}\mathrm{r}=0.90 \\
\mathrm{p}=0.000\end{array}$ & $\begin{array}{l}\mathrm{r}=0.51 \\
\mathrm{p}=0.000\end{array}$ & $\begin{array}{l}r=0.90 \\
p=0.000\end{array}$ & $\begin{array}{l}\mathrm{r}=0.88 \\
\mathrm{p}=0.000\end{array}$ & $\begin{array}{l}\mathrm{r}=0.79 \\
\mathrm{p}=0.000\end{array}$ & $\begin{array}{l}r=0.90 \\
p=0.000\end{array}$ \\
\hline Contribution & $\begin{array}{l}\mathrm{r}=0.82 \\
\mathrm{p}=0.000\end{array}$ & $\begin{array}{l}\mathrm{r}=0.80 \\
\mathrm{p}=0.000\end{array}$ & $\begin{array}{l}\mathrm{r}=0.91 \\
\mathrm{p}=0.000\end{array}$ & $\begin{array}{l}r=0.77 \\
p=0.000\end{array}$ & $\begin{array}{l}\mathrm{r}=0.79 \\
\mathrm{p}=0.000\end{array}$ & $\begin{array}{l}\mathrm{r}=0.91 \\
\mathrm{p}=0.000\end{array}$ & $\begin{array}{l}\mathrm{r}=0.90 \\
\mathrm{p}=0.000\end{array}$ \\
\hline
\end{tabular}

During cluster analysis in the environment of program SPSS, which in intended for processing of quantitative data, 3 groups of respondents were identified:

- young people who evaluate their participation as low or very low, comprehend integration as terminal value and more often have received such socio-pedagogical support as recognition and respect;

- $\quad$ young people who evaluate their participation as average, comprehend integration as instrumental value and more often have received such socio-pedagogical support as encouragement, empathy and mentoring;

- young people who evaluate their participation as high or very high, comprehend integration as opportunate value and more often have received such socio-pedagogical support as trust, cooperation and mentoring.

In the environment of program AQUAD, which in intended for processing of qualitative data, participation implicant was established. It is influenced by comprehension of integration as opportunate value and such socio-pedagogical means as trust, cooperation and mentoring. In this way, the results of qualitative research approved the results of quantitative research.

The stories of youth success prove that manifestations of the terminal value is a quite passive and waiting position, expectation of positive attitude, also fatality and partial dependence on others; integration as an instrumental value expresses itself as independence and self-confidence and confidence about one's power, acquiring new skills and competences, self-actualizing and improving own life quality, but integration as an opporunate value is related to opportunities to acquire new and multiform experience, undertake and overcome 
Tamara Pigozne, Aivars Pigoznis. Socio-Pedagogical Support to Youth Participation in Integration Process

challenges, it is associated to activity, initiative, venture, the emphasis is put on the establishing and maintaining relationships.

Table 2 Correlations between participation categories and means of socio-pedagogical support

\begin{tabular}{|c|c|c|c|c|c|c|c|}
\hline \multirow{2}{*}{$\begin{array}{l}\text { Understan- } \\
\text { ding } \\
\text { of integration }\end{array}$} & \multicolumn{7}{|c|}{ Means of socio-pedagogical support } \\
\hline & $\begin{array}{c}\text { Recogn- } \\
\text { ition }\end{array}$ & Trust & $\begin{array}{c}\text { Encoura- } \\
\text { gement }\end{array}$ & Respect & Empathy & $\begin{array}{c}\text { Coopera- } \\
\text { tion }\end{array}$ & $\begin{array}{l}\text { Mento- } \\
\text { ring }\end{array}$ \\
\hline $\begin{array}{l}\text { Integration as } \\
\text { a terminal } \\
\text { value }\end{array}$ & $\begin{array}{l}\mathrm{r}=0.90 \\
\mathrm{p}=0.000\end{array}$ & $\begin{array}{l}\mathrm{r}=0.49 \\
\mathrm{p}=0.000\end{array}$ & $\begin{array}{l}\mathrm{r}=0.60 \\
\mathrm{p}=0.000\end{array}$ & $\begin{array}{l}\mathrm{r}=0.90 \\
\mathrm{p}=0.000\end{array}$ & $\begin{array}{l}\mathrm{r}=0.55 \\
\mathrm{p}=0.000\end{array}$ & $\begin{array}{l}\mathrm{r}=0.73 \\
\mathrm{p}=0.000\end{array}$ & $\begin{array}{l}\mathrm{r}=0.49 \\
\mathrm{p}=0.000\end{array}$ \\
\hline $\begin{array}{l}\text { Integration as } \\
\text { an } \\
\text { instrumental } \\
\text { value }\end{array}$ & $\begin{array}{l}\mathrm{r}=0.51 \\
\mathrm{p}=0.000\end{array}$ & $\begin{array}{l}r=0.52 \\
p=0.000\end{array}$ & $\begin{array}{l}\mathrm{r}=0.91 \\
\mathrm{p}=0.000\end{array}$ & $\begin{array}{l}r=0.60 \\
p=0.000\end{array}$ & $\begin{array}{l}r=0.90 \\
p=0.000\end{array}$ & $\begin{array}{l}r=0.52 \\
p=0.000\end{array}$ & $\begin{array}{l}\mathrm{r}=0.90 \\
\mathrm{p}=0.000\end{array}$ \\
\hline $\begin{array}{l}\text { Integration as } \\
\text { a value related } \\
\text { to } \\
\text { opportunities } \\
\text { (opportunate) }\end{array}$ & $\begin{array}{l}\mathrm{r}=0.80 \\
\mathrm{p}=0.000\end{array}$ & $\begin{array}{l}r=0.91 \\
p=0.000\end{array}$ & $\begin{array}{l}\mathrm{r}=0.59 \\
\mathrm{p}=0.000\end{array}$ & $\begin{array}{l}\mathrm{r}=0.70 \\
\mathrm{p}=0.000\end{array}$ & $\begin{array}{l}\mathrm{r}=0.59 \\
\mathrm{p}=0.000\end{array}$ & $\begin{array}{l}r=0.91 \\
p=0.000\end{array}$ & $\begin{array}{l}\mathrm{r}=0.90 \\
\mathrm{p}=0.000\end{array}$ \\
\hline
\end{tabular}

Mostly youth participation appears as contribution (69.93\%), involving in various events; in comparison more rarely they involve in co-distribution $(25.72 \%)$ and co-determination $(21.54 \%)$ influencing some processes. The most frequently family was the one who has supported the integration of youth in labour market the most frequently, the least - career consultants and youth work organizers. However, the most frequently teachers/lecturers and family have facilitated the integration of youth in educational system, the least - career consultants and social pedagogues. The involvement of family in facilitation of youth participation should be appreciated; approving also the input of career consultants and social pedagogues, the results perhaps may be explained by the limited human resources in the institutions and their availability to the target audience - youth. Analysing the positive experience in luck-stories, the youth in cooperation with the representative of institutions have emphasized the forms, methods and strategies of work, for instance, identification and profiling, elaboration and implementation of individual action plan, way map for a youth, consultations, whereas in cooperation with family members and friends attitude is the one that dominates. It proves by such mentioned socio-pedagogical means as encouragement, trust and empathy. Mentoring is successful if a mentor undertakes such roles as a friend and advisor.

Youth participation faces influence of various factors, such as education, employment, knowledge of foreign languages, level of income as well as the experience of non-formal and informal education. The results of Kruskal-Walis 
H-test indicate that statistically significant difference exists which depends on education, employment, knowledge of foreign languages, level of income, as well as experience of non-formal and informal education in comprehension of integration as valuable issue, efficient participation and identification of sociopedagogical means in success stories of the respondents: entrepreneurs and young people with higher education, knowledge of three or more foreign languages, high income, as well as various experience of non-formal and informal education, have emphasized integration as potential value, participation and socio-pedagogical support more often in comparison with unemployed persons, NEETs, young people with elementary education, low income, knowledge of one foreign language and limited experience of non-formal and informal education (see Table 3 ).

Table 3 Significant differences of participation

\begin{tabular}{|c|c|c|c|c|}
\hline Factors & $\begin{array}{l}\text { Chi-Square test } \\
\text { results }\end{array}$ & $\begin{array}{c}\text { Mann-Whitney } \\
\text { U-test / Kruskal- } \\
\text { Wallis H-test } \\
\text { results }\end{array}$ & $\begin{array}{l}\text { The highest } \\
\text { value }\end{array}$ & The lowest value \\
\hline Education & $\begin{array}{l}\chi^{2}(2)=17.530 \\
p=0.000\end{array}$ & $\mathrm{p}=0.000$ & $\begin{array}{l}\text { young people } \\
\text { with higher } \\
\text { education (Mean } \\
\text { Rank=92.00) }\end{array}$ & \begin{tabular}{l}
\multicolumn{1}{c}{ young people } \\
with elementary \\
education (Mean \\
Rank=113.50)
\end{tabular} \\
\hline Employment & $\begin{array}{l}\chi^{2}(2)=15.223 \\
p=0.000\end{array}$ & $\mathrm{p}=0.000$ & $\begin{array}{l}\text { entrepreneurs } \\
\text { (Mean } \\
\text { Rank=111.15) }\end{array}$ & $\begin{array}{l}\text { unemployed, } \\
\text { NEETs (Mean } \\
\text { Rank=147.00) }\end{array}$ \\
\hline $\begin{array}{l}\text { The experience of } \\
\text { non-formal and } \\
\text { informal } \\
\text { education }\end{array}$ & $\begin{array}{l}\chi^{2}(2)=13.820 \\
p=0.000\end{array}$ & $\mathrm{p}=0.000$ & $\begin{array}{l}\text { young people } \\
\text { with various } \\
\text { experience of } \\
\text { non-formal and } \\
\text { informal } \\
\text { education (Mean } \\
\text { Rank=134.50) }\end{array}$ & $\begin{array}{l}\text { young people } \\
\text { with limited } \\
\text { experience of } \\
\text { non-formal and } \\
\text { informal } \\
\text { education (Mean } \\
\text { Rank=172.50) }\end{array}$ \\
\hline Level of income & $\begin{array}{l}\chi^{2}(2)=17.490 \\
p=0.000\end{array}$ & $\mathrm{p}=0.000$ & $\begin{array}{l}\text { young people } \\
\text { with high income } \\
(\text { Mean } \\
\text { Rank=145.00) } \\
\end{array}$ & $\begin{array}{l}\text { young people } \\
\text { with low income } \\
(\text { Mean } \\
\text { Rank=169.50) }\end{array}$ \\
\hline Languages & $\begin{array}{l}\chi^{2}(2)=19.778 \\
p=0.000\end{array}$ & $\mathrm{p}=0.000$ & $\begin{array}{l}\text { young people } \\
\text { with knowledge } \\
\text { of three or more } \\
\text { foreign languages } \\
(\text { Mean } \\
\text { Rank=123.00) }\end{array}$ & $\begin{array}{l}\text { young people } \\
\text { with knowledge } \\
\text { of one foreign } \\
\text { language } \\
\text { (Mean } \\
\text { Rank=155.50) }\end{array}$ \\
\hline
\end{tabular}

Income influences availability of education to a large extent, thus causing separation of young people as a large part of the society. 
Tamara Pigozne, Aivars Pigoznis. Socio-Pedagogical Support to Youth Participation in Integration Process

\section{Conclusions}

1. Integration as values orientation is a system of convictions, viewpoints and priorities developed by a youth her/himself. The system is based on her/his chosen attitude towards values and it appears in one's point of view and actions within the process of integration as a terminal value (view of integration as restriction), instrumental (as a mean of reaching other objectives), but perhaps as a system of opportunities, advantages for selffulfilment in educational system and labour market (opportune value).

2. Integration is a multidimensional process of communication: from the outlook of an individual it is identification of values, from micro-prospect participation, from mezzo and macro prospect - affiliation.

3. Recognition and empathy mostly facilitate co-determination; encouragement and cooperation - contribution, trust and respect - codistribution; but mentoring facilitates all the categories of participation.

4. Youth participation in the process of integration in educational system and labour market as understanding a value - it is facilitated by understanding integration as value related to opportunities. Perceiving integration as new opportunities youth discern self-fulfilment opportunities while contributing, co-distributing and co-determining.

5. The youth who understand integration as a value related to opportunities and receive socio-pedagogical support in facilitation of their participation, integrate in educational system and labour market more successfully.

6. Profile of the respondents influences comprehension of integration as valuable issue, participation and socio-pedagogical support. Education, employment and knowledge of foreign languages, level of income as well as experience of non-formal and informal education is the most significant factors which influence participation of young people in integration education system and labour market.

7. Facilitation of participation of young people in integration education system and labour market depends on holistic approach and usage of collaboration socio-pedagogical means of social and strategic partners, forms of work, methods and strategies.

\section{References}

Arnstein, S.R. (1969). Ladder of Citizen Participation. Journal of the American Institute Planner, 35. Jg. 1969, 216 - 224.

Buchkremer, H. (1995). Handbuch Sozialpädagogik: Dimensionen sozialer und gesellschaftlicher Entwicklungen durch Erziehung. Darmstadt: Wissenschaftliche Buchgesellschaft. 
Checkoway, B. (1998). Involving young people in neighborhood development. Children and Youth Services Review, 20, 765-795.

Checkoway, B. \& Richards-Schuster, K. (2003). Youth Participation in Community Evaluation Research. American Journal of Evaluation, 24(1), 2003, 21-33.

Dam, L., Hufeisen, B. (1995). Undervisningdifferentiering i fremmedsprog. Foreng Malling Back.

Donaldson, S. I., Ensher, E. A., \& Grant-Vallone, E. J. (2000). Longitudinal examination of mentoring relationships on organizational commitment and citizenship behavior. Journal of Career Development, 26, 233-249.

Eurydice Brief: Early Leaving from Education and Training (2015). Education, Audiovisual and Culture Executive Agency.

http://www.viaa.gov.lv/lat/izglitibas_petijumi/eurydice/eurydice_publikacijas/

Europa 2020. A European strategy for smart, sustainable and inclusive growth (2010). Brussels, European Commision. http://ec.europa.eu/eu2020/pdf/COMPLET\%20EN\%20 BARROSO\%20\%20\%20007\%20-\%20Europe\%202020\%20-\%20EN\%20version.pdf

Flusser, V. (1994). Von der Freiheit des Migranten. Köln.

Frankl, E.V. (1946). Trotzdem Ja Zum Leben Sagen: Ein Psychologe erlebt das Konzentrationslager. Verlag für Jugend und Volk.

Freire, P. (1970). Pedagogy of the Oppressed. New York: Seabury Press, 1970.

Friedman, T. (2005). The World Is Flat. A Brief History of the Twenty-first Century. Published by Farrar, Straus \& Giroux, Hardcover.

Harder, M.K., Burford, G., \& Hoover, E. (2013). What Is Participation? Design Leads the Way to a Cross-Disciplinary Framework. DesignIssues: Volume 29, Number 4 Autumn 2013, 41-57.

Held, J. (2009). Wege der Integration imerziehungs- und Bildungsprozess- internationale Perspektiven. In: Sauer, K., Held, J. (Hrsg.) Wege der Integration in heterogenen Gesellschaften. Wiesbaden: Verlag. S. $7-12$.

Held, J. \& Riegel, C. (1999). Integrations - und Ausgrenzungsprobleme Jugendlicher. In: Held, J., Spona, A. A. (Hg.): Jugend zwischen Ausgrenzung und Integration. Ergebnisse eines internationalen Forschungsprojekts. Riga, Hamburg, S. 59-88.

Informatīvais ziņojums par jauniešu garantijas īstenošanu Latvijā 2014.-2018.gadā. (2013). Rīga. http://www.lm.gov.lv/upload/jauniesiem/lmzin_jg_171213.pdf

Jaunieši darba tirgū: situācijas un nodarbinātību ietekmējošo faktoru analīze. Rīga, Sociologisko pētījumu institūts, 2007.

Jones, K. (1996). Trust as an Affective Attitude, Ethics, 107:1 (October), pp. 4-25.

Kalpaka, A. (1986). Handlungsfähigkeit statt „Integration”. Schulische und ausserschulische Lebensbedingungen und Entwicklungsmöglichkeiten griechischer Jugendlicher. Weinheim, München.

Karpova, Ā. (1994). Personība un individuālais stils. Rīga.

Kirby, P., Lanyon, C., Cronin, K. \& Sinclair, R. (2003). Building a Culture of Participation. National Children's Bureau.

Klafki, W. (1991). Neue Studien zur Bildungstheorie und Didaktik: Zeitgemässe Allgemeinbildung und kritisch-konstruktive Didaktik. Weinheim, Basel.

Kreckel, R. (1994) Soziale Integration und nationale Identität. In: Berliner Journal für Soziologie, 4. Jg., Heft 1, S. 13 - 20.

Maslo, I. (2002). Mazākumtautību pamatizglītības programmu ieviešanas monitorings. In: Decade of reform: Achievements, Challengies, Problems. Rīga. 
Tamara Pigozne, Aivars Pigoznis. Socio-Pedagogical Support to Youth Participation in Integration Process

Mecheril, P. (2003). Prekäre Verhältnisse. Über natio - ethno - kulturell (Mehrfach-) Zugehörigkeit. Münster.

Metodologiskās vadlīnijas darbam ar mērksa grupas jauniešiem projektā „Proti un dari!’” (2015). Rīga, Jaunatnes starptautisko programmu aǵentūra. http://jaunatne.gov.lv/ sites/default/files/web/Jauniesu_garantija/jaunumi/metodologiskas_vadlinijas_19_10_2 015.pdf

Morales, A.T. \& Sheafor, B.W. (2011). Social work: A profession of many faces. Prentice Hall.

Olk, Th. (1994). Jugendhilfe als Diensleistung. Widersprüche, 53. Jg. S. 11 - 33.

Otto, H. U. \& Thiersch, H. (2001). Handbuch der Sozialarbeit. Sozialpädagogik. Luchterhand.

Parsons, R.M. (2011). Fundamentals of the Helping Process. 2nd Edition. Waveland Press. Available at: https://books.google.lv

Percy-Smith, B. \& Thomas, N. (2010). A Handbook of Children and Young People's Participation, Routledge.

Petersen, K. (1999). Neuorientierung im Jugendamt. Neuwied.

Riegel, C. (2009). Integration - ein schlagwort? Zum umgang mit einem problematischen Begriff. In: Sauer K. E., Held J. (Hrsg.) Wege der Integration in heterogenen Gesellschaften. Wiesbaden: Verlag. S. 23 - 40.

Riegel, C. (2004). Im Kampf um Zugehörigkeit und Anerkennung. Frankfurt am Main. London. Rokeach, M. (1979). Understanding human values: individual and societal. N. Y.: Free Press.

Sniķere, S., Koroḷeva, I., Aleksandrovs, A. \& Kārkliņa, I. (2010). Research on the Training Needs and Interests of Youth in Remote or Underdeveloped Regions. Institute for Sociological Research, Riga.

Sotkasiira, T., Haikkola, L. \& Horelli, L. (2010). Building towards effective participation: alearning-based network approach to youth participation. In: A Handbook of Children and Young People's Participation. Perspectives from theory and practice, Routledge, 174-183.

Small, S. \& Memmo, M. (2004). Contemporary Models of Youth Development and Problem Prevention: Toward an Integration of Terms, Concepts, and Models.

Šulcs, D. (2005). Uzticēšanās skolotāja un skolēna attiecībās. Skolotājs, Nr. 6.,7. - 13.

Warren, M. E. (1993). Can Participatory Democracy Produce Better Selves? Political Psychology, 14, Jg. S. 2009 - 234.

Weber, M. (2007). Ethnisierung und männlicher Gewalt. Männlichkeit und Herkunft als Orientierung und Falle. In: Riegel C., Geisen T. (Hrsg.) Jugend, Zugehörigkeit und Migration. Wiesbaden: Verlag. S. $307-322$.

Working on work for all (2009). SALTO-YOUTH Inclusion Resource Centre https://www.salto-youth.net/downloads/4-17-1948/WorkingOnWork.pdf

Youth in Labour Market: Analysis of the Situation and Factors Influencing Employment. (2007). Riga, Institute for Sociological Research.

Youth Participation Guide: Assessment, Planning and Implementation. (2008). A Family Health International. lementation 